\title{
Oceanography
}

CITATION

Perry, M.J. 2016. The optical oceanography class turned 30 in summer 2015.

Oceanography 29(1):32-33, http://dx.doi.org/10.5670/oceanog.2016.07.

DOI

http://dx.doi.org/10.5670/oceanog.2016.07

COPYRIGHT

This article has been published in Oceanography, Volume 29, Number 1, a quarterly journal of The Oceanography Society. Copyright 2016 by The Oceanography Society. All rights reserved.

USAGE

Permission is granted to copy this article for use in teaching and research. Republication, systematic reproduction, or collective redistribution of any portion of this article by photocopy machine, reposting, or other means is permitted only with the approval of The Oceanography Society. Send all correspondence to: info@tos.org or The Oceanography Society, PO Box 1931, Rockville, MD 20849-1931, USA. 


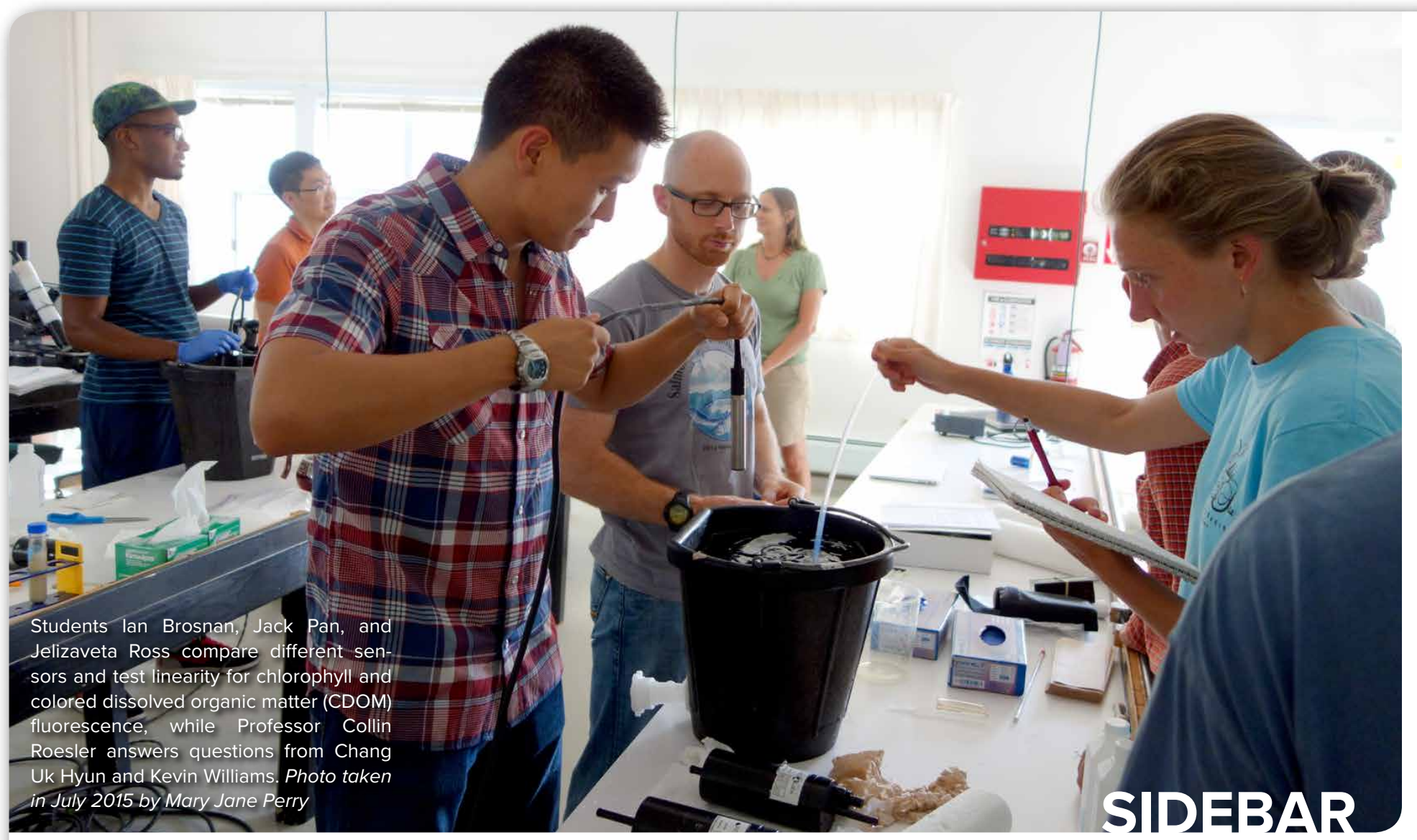

\section{The Optical Oceanography Class Turned 30 in Summer 2015}

\section{By Mary Jane Perry}

The Optical Oceanography graduate course has been offered for 30 years, typically every other summer, with a few longer gaps from time to time. Over 200 graduate students, postdocs, and other professionals from around the United States and all over the world have taken and benefited from the course. Students come from a diversity of backgrounds and interests, ranging from primary productivity, harmful algal blooms, and biogeochemical cycling to sediment transport and more. What binds these students together is a desire to learn how to use and apply optical measurements to address science and management questions. Past graduates of the course are today's leaders in the field, working in government, academia, and industry; the class's more recent graduates are well on their ways to join the past graduates in leadership roles.

The course provides students with a fundamental knowledge of ocean optics and optical sensor technology that enables them to make quality measurements, assess the uncertainties associated with the measurements, and compare these data with remotely sensed ocean color measurements and products derived from them. The goal of the course is to prepare a new generation of oceanographers trained in the use of optics to study the ocean at scales from the single cell to the entire globe. The course includes lectures, hands-on labs, modeling labs, field data collection, data submission to SeaBASS (NASA's optical database; http://seabass.gsfc.nasa.gov), daily student reports, discussions, and student projects.

Since its beginnings, the course has been offered at "off the beaten track" marine labs that offer far fewer distractions than urban campuses and that provide a family-like setting for learning, living, and eating. The students live in a dormitory, and the faculty live in cabins or apartments on the marine lab grounds. The living and eating together are just as important as formal class experiences; they contribute to creating a virtual community that persists beyond the actual class. The course creates a supportive learning environment that gives students the opportunity and stimulus to integrate field measurements with the underlying science. Core faculty participate for the full class (now four-weeks duration). By involving other faculty who can participate for only one to two weeks, students are exposed to a diversity of philosophies and perspectives for measuring optics in the field, interpreting data, and integrating data with models. In 1989, the course even sponsored an ocean optics symposium, inviting the key leaders in the international optical oceanography community (Spinrad et al., 1994) and giving students a chance to talk-and play softball-with luminaries like Andre Morel, John Kirk, Ron Zaneveld, George Kattawar, and others.

The Optical Oceanography course was initiated in 1985 at the University of Washington's Friday Harbor Laboratories (FHL) by me, then at the University of Washington, and Kendall Carder at the University of South Florida. It was a five-week course. At that time, bio-optical oceanography was a new field with few opportunities for students to learn integrated theory and measurement in a multidisciplinary setting. The dialogue between biologists and physical optical oceanographers was limited, as was the diversity and sophistication of in situ instrumentation. Looking back, it was audacious, even foolhardy, but we offered the course instrumented with only a few borrowed Li-Cor cosine PAR sensors, a bench-top Brice Phoenix scattering sensor, water sampling and filtering equipment, a brand new Aminco spectrophotometer, and several desktop Macintosh computers that students could sign up to use. What we lacked in instrumentation we countered with lots of enthusiasm and energy. 
The FHL class started at 0800 with an hour and half lecture from Ken, a long break, and an hour and half lecture by me. Much of the break was occupied by lively discussions, as Ken and I learned how to integrate biology and optics and to speak the same language. We each attended the other's lectures and, during that first summer, the instructors learned way more than the students. The FHL format of morning lectures and afternoon labs punctuated with field sampling continues, with some modifications, to the present. Saturday mornings were spent in learning-through-discussion sessions, where students would deconstruct and reconstruct a difficult optics paper. The reward was watching a sequence of "aha" expressions on the students' faces. Most Saturday nights were spent on the deck of the FHL faculty apartment complex, with us feeding the students homecooked meals and providing a forum for informal discussions. Other nights, I am sure, students would row to the town of Friday Harbor to visit that venerable establishment, Herb's. During the last of the five weeks, students worked on individual or team projects, culminating with a student symposium and salmon feast. Two additional core faculty started teaching the course while at FHL. Collin Roesler, now at Bowdoin College, was a student of the second class, was the teaching assistant for the third class, and joined the faculty for the fourth class. Curtis Mobley, from Sequoia Scientific, has been a core faculty member for the past 20 years.

In 1999, when I moved to the University of Maine's Ira C. Darling Center, the course moved, too. Emmanuel Boss, a former optical oceanography student and later teaching assistant who had recently joined the faculty at UMaine, became co-director of the course in 2004, and in 2007 took over as director (he had joined as a core faculty member in 2001). The course has evolved over the years and currently focuses on the application of in situ measurements and modeling for calibration and validation of remote-sensing ocean color. The instrumentation has expanded since the early days of the course, and students now have hands-on access to an incredible diversity of absorption types, scattering, attenuation, and fluorescence sensors matched with a similar diversity of in-water and above-water radiometers. Faculty freely distribute processing codes in both Excel and MATLAB, and students formally submit field data to SeaBASS. Closure, redundancy, and calibration are course bywords.

Students Chang Uk Hyun and Kevin Williams consider the best strategy for measuring fluorescence in the teaching classroom. Photo taken in July 2015 by Mary Jane Perry

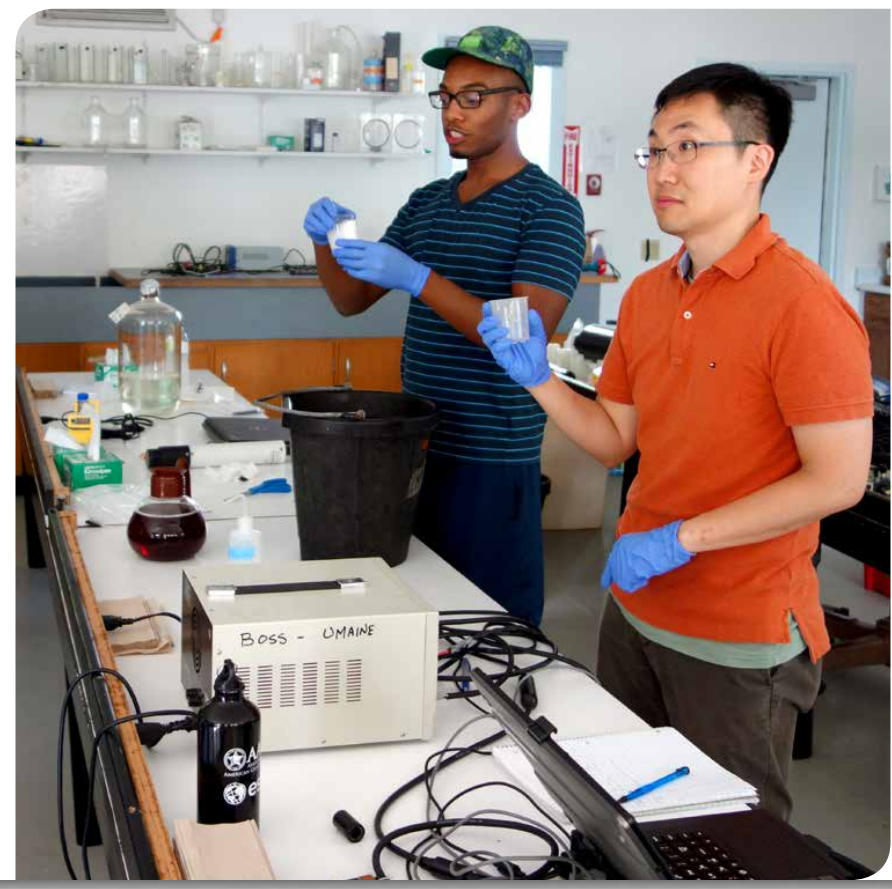

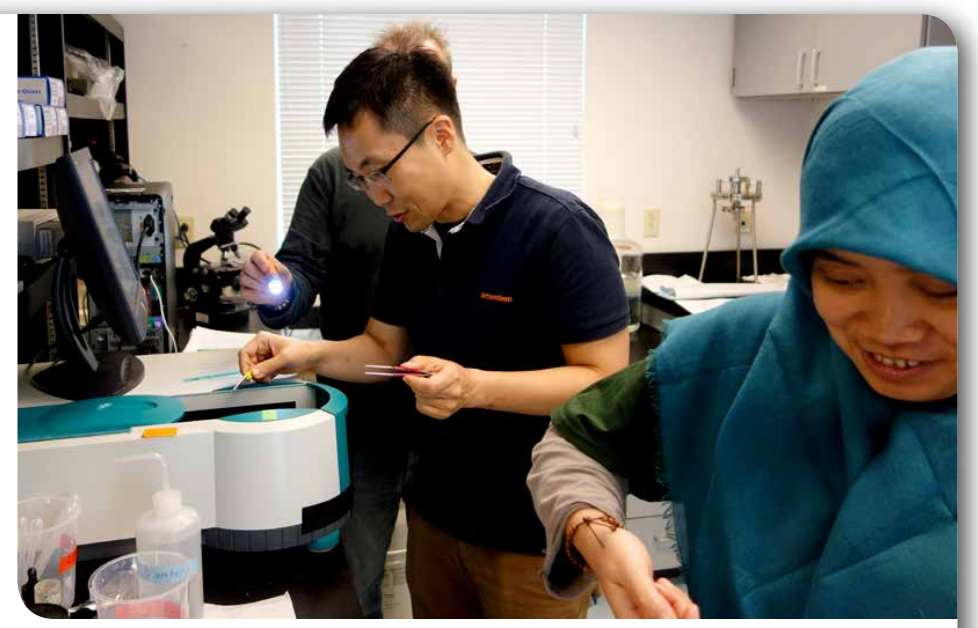

Students Chang Uk Hyun and Ike Astuti measure particulate absorption spectra of samples from the Damariscotta River estuary in Mary Jane Perry's lab. Photo taken in July 2015 by Mary Jane Perry

While lectures and formal labs remain the class's core, a valuable recent introduction has been the daily student reports. At night, students work collaboratively to process, organize, and interpret the data from the afternoon's formal laboratory or field expedition. They self-organize and every morning report to the class step-bystep results of data processing and analysis. Fellow students and instructors comment, leading to interesting discussions of problems and suggestions for solutions. Student reporting is a great learning experience, although initially stressful for some students; the genuine desire of the faculty to support students helps to dispel at least some of the initial anxiety.

The class website contains all lectures (PowerPoint presentations and videos), labs, and student projects, allowing students who could not be accommodated in the 20 available positions to access the course materials (https://sites.google.com/site/oceanopticsclass/ schedule). A spin-off from the course is the Ocean Optics Web Book, the brain child of Curtis Mobley, with collaborative submissions by several of the instructors; it is a free, Web-based, continually updated resource that addresses both education and reference needs of the broad optical and ocean color remote sensing communities (http://www.oceanopticsbook.info). The members of the Optical Oceanography faculty now include Emmanuel Boss and myself from the University of Maine, Collin Roesler from Bowdoin College, Curtis Mobley from Sequoia Scientific Inc., Ivona Cetinic and Jeremy Werdell from NASA Goddard, and Kenneth Voss from the University of Miami. Even after 30 years, the faculty members attend all lectures and remain committed to training the next generation not only in measurements, models, and theory, but also in team work and collaboration. With luck, the class and its leadership will continue to evolve and stay vibrant for decades to come.

REFERENCE

Spinrad, R.W., K.L. Carder, and M.J. Perry, eds. 1994. Ocean Optics. Oxford University Press, NY.

\section{ACKNOWLEDGMENTS}

Support over the years from the following is gratefully acknowledged: the University of Washington's Friday Harbor Laboratories, the University of Maine and the Ira C. Darling Marine Center, the Office of Naval Research, the Nationa Science Foundation, and NASA's Ocean Biology and Biogeochemistry Program (current sponsor).

\section{AUTHOR}

Mary Jane Perry (perrymj@maine.edu) is Professor, School of Marine Sciences, Darling Marine Center, University of Maine, Walpole, ME, USA.

\section{ARTICLE CITATION}

Perry, M.J. 2016. The optical oceanography class turned 30 in summer 2015 Oceanography 29(1):32-33, http://dx.doi.org/10.5670/oceanog.2016.07. 